\title{
Front Matter: Volume 7717
}

, "Front Matter: Volume 7717," Proc. SPIE 7717, Optical Modelling and Design, 771701 (9 July 2010); doi: 10.1117/12.867351

SPIE. Event: SPIE Photonics Europe, 2010, Brussels, Belgium 


\title{
PROCEEDINGS OF SPIE
}

\section{Optical Modelling and Design}

\author{
Frank Wyrowski \\ John T. Sheridan \\ Jani Tervo \\ Youri Meuret \\ Editors
}

13-15 April 2010

Brussels, Belgium

Sponsored by

SPIE

Cosponsored by

B-PHOT_Brussels Photonics Team (Belgium) • Brussels-Capital Region (Belgium) • FWO_Fonds Wetenschappelijk Onderzoek (Belgium) • ICO_International Commission for Optics $\bullet$ Ville de Bruxelles (Belgium)

Cooperating Organisations

CBO-BCO (Belgium) • EOS—European Optical Society (Germany) • IET-The Institution of

Engineering and Technology (United Kingdom) • IOP-Institute of Physics (United Kingdom)

Photonics4Life (Germany) - Photonics@be (Belgium) - Photonics 21 (Germany) • PromOptica (Belgium)

Published by

SPIE

Volume 7717

Proceedings of SPIE, 0277-786X, v. 7717 
The papers included in this volume were part of the technical conference cited on the cover and title page. Papers were selected and subject to review by the editors and conference program committee. Some conference presentations may not be available for publication. The papers published in these proceedings reflect the work and thoughts of the authors and are published herein as submitted. The publisher is not responsible for the validity of the information or for any outcomes resulting from reliance thereon.

Please use the following format to cite material from this book:

Author(s), "Title of Paper," in Optical Modelling and Design, edited by Frank Wyrowski, John T. Sheridan, Jani Tervo, Youri Meuret, Proceedings of SPIE Vol. 7717 (SPIE, Bellingham, WA, 2010) Article CID Number.

ISSN 0277-786X

ISBN 9780819481900

Published by

SPIE

P.O. Box 10, Bellingham, Washington 98227-0010 USA

Telephone +1 3606763290 (Pacific Time) · Fax +1 3606471445

SPIE.org

Copyright (C) 2010, Society of Photo-Optical Instrumentation Engineers

Copying of material in this book for internal or personal use, or for the internal or personal use of specific clients, beyond the fair use provisions granted by the U.S. Copyright Law is authorized by SPIE subject to payment of copying fees. The Transactional Reporting Service base fee for this volume is $\$ 18.00$ per article (or portion thereof), which should be paid directly to the Copyright Clearance Center (CCC), 222 Rosewood Drive, Danvers, MA 01923. Payment may also be made electronically through CCC Online at copyright.com. Other copying for republication, resale, advertising or promotion, or any form of systematic or multiple reproduction of any material in this book is prohibited except with permission in writing from the publisher. The CCC fee code is 0277-786X/10/\$18.00.

Printed in the United States of America.

Publication of record for individual papers is online in the SPIE Digital Library.

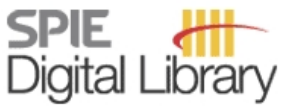

SPIEDigitalLibrary.org

Paper Numbering: Proceedings of SPIE follow an e-First publication model, with papers published first online and then in print and on CD-ROM. Papers are published as they are submitted and meet publication criteria. A unique, consistent, permanent citation identifier (CID) number is assigned to each article at the time of the first publication. Utilization of CIDs allows articles to be fully citable as soon they are published online, and connects the same identifier to all online, print, and electronic versions of the publication. SPIE uses a six-digit CID article numbering system in which:

- The first four digits correspond to the SPIE volume number.

- The last two digits indicate publication order within the volume using a Base 36 numbering system employing both numerals and letters. These two-number sets start with 00, 01, 02, 03, 04, $05,06,07,08,09,0 A, 0 B \ldots 0 Z$, followed by 10-1Z, 20-2Z, etc.

The CID number appears on each page of the manuscript. The complete citation is used on the first page, and an abbreviated version on subsequent pages. Numbers in the index correspond to the last two digits of the six-digit CID number. 


\section{Contents}

ix Conference Committee

\section{SESSION 1 SUBWAVELENGTH STRUCTURES}

771702 High Q polarization independent guided mode resonance filters with doubly periodic etched $\mathrm{Ta}_{2} \mathrm{O}_{5}$ bi-dimensional grating [7717-01]

A.-L. Fehrembach, F. Lemarchand, Institut Fresnel, CNRS, Aix-Marseille Univ. (France);

A. Talneau, Lab. de Photonique et de Nanostructures, CNRS (France); A. Sentenac, Institut Fresnel, CNRS, Aix-Marseille Univ. (France)

771703 Simulations of nano-optics devices with a fast B-spline modal method Best Student Paper Award [7717-02]

P. Bouchon, ONERA (France) and Lab. de Photonique et Nanostructures, CNRS (France);

F. Pardo, Lab. de Photonique et Nanostructures, CNRS (France); R. Haïdar, ONERA (France);

J.-L. Pelouard, Lab. de Photonique et Nanostructures, CNRS (France)

771704 Interpolatory fixed-point algorithm for an efficient computation of TE and TM modes in arbitrary 1D structures at oblique incidence [7717-03]

M. Pérez Molina, J. Francés Monllor, M. Álvarez López, C. Neipp López, Univ. de Alicante (Spain); L. Carretero López, Univ. Miguel Hernández de Elche (Spain)

771706 Transference matrix method for non slanted holographic reflection gratings [7717-05] C. Neipp, J. Francés, M. Pérez-Molina, S. Bleda, A. Beléndez, Univ. de Alicante (Spain)

$771707 \quad$ Modelling light propagation in plasmonic nanostructures [7717-06] T. Samrowski, Univ. Zürich (Switzerland); L. Raguin, C. Hafner, R. Vahldieck, Swiss Federal Institute of Technology (Switzerland)

771708 Near field dielectric microlenses [7717-07]

A. Devilez, N. Bonod, B. Stout, Institut Fresnel, CNRS, Aix-Marseille Univ. (France)

771709 Characterization of the scattering effect of complex mask geometries with surface roughness [7717-08]

Z. Rahimi, A. Erdmann, Fraunhofer Institute for Integrated Systems and Device Technology (Germany) and Erlangen Graduate School in Advanced Optical Technologies (Germany); C. Pflaum, Erlangen-Nuremberg Univ. (Germany) and Erlangen Graduate School in Advanced Optical Technologies (Germany)

\section{SESSION 2 WAVE OPTICS I}

7717 OC Influence of fiber injection on square fiber optic homogenizer [7717-11]

T. Lizotte, Hitachi Via Mechanics USA, Inc. (United States) 
7717 OD Generation of diffractive optical elements onto a photopolymer using a liquid crystal display [7717-12]

A. Márquez, S. Gallego, M. Ortuño, E. Fernández, M. L. Álvarez, A. Beléndez, I. Pascual, Univ. de Alicante (Spain)

7717 OE Stochastic optimization of radial DOE forming intensity distribution along an axial focal zone [7717-13]

D. G. Kachalov, Samara State Aerospace Univ. (Russian Federation); V. S. Pavelyev, S. N. Khonina, R. V. Skidanov, Samara State Aerospace Univ. (Russian Federation) and Image Processing Systems Institute (Russian Federation); O. Yu. Moiseev, Image Processing Systems Institute (Russian Federation)

\section{SESSION $3 \quad$ NEW STRATEGIES IN OPTICAL DESIGN}

7717 OF Systematics of the design shapes in the optical merit function landscape (Invited Paper) [7717-14]

F. Bociort, P. van Grol, Delft Univ. of Technology (Netherlands)

7717 OG Optics cost modelling and design optimization (Invited Paper) [7717-15]

J.-T. Mäkinen, VTT Technical Research Ctr. of Finland (Finland); S. Nollau, Fraunhofer Institute for Production Technology (Germany)

$7717 \mathrm{OH} \quad$ Robust design approach in micro optics [7717-16]

I. Sieber, M. Dickerhof, Karlsruhe Institute of Technology (Germany)

\section{SESSION 4 ILLUMINATION SYSTEMS}

771701 Applications of the SMS method to the design of compact optics (Invited Paper) [7717-17] J. C. Miñano, P. Benítez, Univ. Politécnica de Madrid (Spain) and LPI (United States); J. Liu, J. Infante, Univ. Politécnica de Madrid (Spain); J. Chaves, LPI (United States); L. Wang, Univ. Politécnica de Madrid (Spain)

$77170 \mathrm{~J}$ Modelling the spatial colour distribution of phosphor-white high power light-emitting diodes [7717-18]

A. Keppens, Catholic Univ. College Gent (Belgium) and Katholieke Univ. Leuven (Belgium); S. Denijs, S. Wouters, Catholic Univ. College Gent (Belgium); W. R. Ryckaert, Catholic Univ. College Gent (Belgium) and Katholieke Univ. Leuven (Belgium); G. Deconinck, Katholieke Univ. Leuven (Belgium); P. Hanselaer, Catholic Univ. College Gent (Belgium) and Katholieke Univ. Leuven (Belgium)

$7717 \mathrm{OL}$ Feasibility study of a brute-force ray tracing approach to obtain luminance maps of luminaires modeled with ray files [7717-20]

J. Audenaert, G. Durinck, F. Vandeghinste, Katholieke Hogeschool Sint-Lieven (Belgium); G. Deconinck, Katholieke Univ. Leuven (Belgium); P. Hanselaer, Katholieke Hogeschool Sint-Lieven (Belgium) and Katholieke Univ. Leuven (Belgium)

7717 OM Design and optimization of automotive headlamps based on projection system with double ellipsoidal reflector [7717-21]

C.-T. Ma, K.-H. Chou, Y.-Y. Chen, A. J.-W. Whang, K.-Y. Chen, National Taiwan Univ. of Science and Technology (Taiwan) 
$7717 \mathrm{ON}$ Ray tracing analysis of light scattering properties of randomly nano-textured ZnO films [7717-22]

M. Schulte, K. Bittkau, B. E. Pieters, S. Jorke, Forschungszentrum Jülich GmbH (Germany);

H. Stiebig, Malibu GmbH \& Co. KG (Germany); J. Hüpkes, U. Rau, Forschungszentrum Jülich

GmbH (Germany)

\section{SESSION 5 HOLOGRAPHIC MODELLING}

$771700 \quad$ Imaging micro-optical components with short coherent digital holographic microscopy [7717-23]

S. Stuerwald, R. Schmitt, Fraunhofer Institute for Production Technology (Germany)

7717 OP Multispectral lensless digital in-line holographic microscope: LED illumination [7717-24]

J. P. Ryle, S. McDonnell, J. T. Sheridan, Univ. College Dublin (Ireland)

$77170 Q$ Study of influence of ACPA in holographic reflection gratings recorded in PVA/AA based photopolymer [7717-25]

R. Fuentes, E. Fernández, C. García, A. Beléndez, I. Pascual, Univ. de Alicante (Spain)

7717 OR Radiation of difference frequencies at optical rectification of spatially limited femtosecond laser pulse in the periodically poled GaAs crystal [7717-36]

A. S. Martirosyan, D. L. Hovhannisyan, Yerevan State Univ. (Armenia); V. O. Chaltikyan, Institute for Physical Research (Armenia); G. D. Hovhannisyan, Yerevan State Univ.

(Armenia)

7717 OS Approximating monomer diffusion in the Raman-Nath regime [7717-27]

C. E. Close, M. R. Gleeson, J. T. Sheridan, Univ. College Dublin (Ireland)

\section{SESSION 6 WAVE OPTICS II}

7717 OT Wave optical simulation of a spectral narrowed resonator [7717-28]

H. Gross, Carl Zeiss AG (Germany)

7717 OU Enabling aberration retrieval of microlenses with the Extended Nijboer-Zernike (ENZ) diffraction theory [7717-29]

S. van Haver, J. J. M. Braat, S. F. Pereira, Delft Univ. of Technology (Netherlands)

7717 OV Scalar product technique in modal decomposition for multimode fibers [7717-30]

D. M. Nguyen, Univ. Européenne de Bretagne, Lab. Foton, CNRS (France) and CCLO-FOTON, ENSSAT (France); T. N. Nguyen, Posts and Telecommunications Institute of Technology (Vietnam); S. Blin, Institut d'Électronique du Sud, CNRS, Univ. de Montpellier II (France); M. Thual, Univ. Européenne de Bretagne, Lab. Foton, CNRS (France) and CCLO-FOTON, ENSSAT (France); T. Chartier, Univ. Européenne de Bretagne, Lab. Foton, CNRS (France)

7717 OW Non-Bragg bandgaps, resonances, and Gaussian beam propagation in superlattices composed from negative index metamaterials [7717-31]

M. Maksimovic, MECAL BV (Netherlands) 
7717 OX Fixed weight Hopfield Neural Network based on optical implementation of all-optical MZI-XNOR logic gate [7717-32]

K. Nugamesh Mutter, M. Z. Mat Jafri, A. Abdul Aziz, Univ. Sains Malaysia (Malaysia)

POSTER SESSION

7717 OY Theoretical analysis and experimental validation of photosensitizer diffusion in a photopolymer material [7717-26]

J. Guo, S. Liu, M. R. Gleeson, J. T. Sheridan, Univ. College Dublin (Ireland)

$77170 Z$ A new method to validate the usage of Fresnel approximation instead of Kirchhoff diffraction formula for calculations concerning camera systems [7717-33]

U. Talbiersky, Institute of Robotics and Mechatronic, DLR (Germany)

771711 Hemispherical projection lens for insect behavior analysis [7717-35]

M. Aikio, VTT Technical Research Ctr. of Finland (Finland); J. Takalo, M. Lempeä,

M. Vähäsöyrinki, Univ. of Oulu (Finland)

771712 Innovative flooded mask for a well-corrected vision both under water and above water [7717-37]

L. Mercatelli, E. Sani, P. Sansoni, F. Francini, D. Jafrancesco, D. Fontani, INO-CNR National Institute of Optics (Italy)

771713 The design of optical module of LED street lamp with non-axial symmetrical reflector [7717-38]

M.-J. Lu, C.-A. Chen, Y.-Y. Chen, A. J.-W. Whang, National Taiwan Univ. of Science and Technology (Taiwan)

771714 Design and measurement of TIR lens of MR16-compatible LED lamp without aspherical surface for high directivity [7717-39]

W.-C. Hsieh, Y.-Y. Chen, Y.-C. Lee, A. J.-W. Whang, National Taiwan Univ. of Science and Technology (Taiwan)

771715 Simulation analysis of a novel bandpass fiber filter [7717-40]

X. Wu, J. Jacquet, Supélec, LMOPS (France); G. Duan, Alcatel-Thalès III-V Lab. (France)

771716 New photopolymers with high environmental compatibility: biophotopol compared to PVA/AA materials at zero spatial frequency limit [7717-41]

S. Gallego, A. Márquez, M. Ortuño, S. Marini, D. Méndez, Univ. d'Alacant (Spain) and I.U. Fisica Aplicada a Las Ciencias y Las Tecnologías (Spain); I. Pascual, I.U. Fisica Aplicada a Las Ciencias y Las Tecnologías (Spain) and Univ. d'Alacant (Spain)

771717 Approximate analysis of nonlinear operation of triangular lattice photonic crystal laser [7717-42]

M. Koba, P. Szczepański, Warsaw Univ. of Technology (Poland) and National Institute of Telecommunications (Poland)

771718 Modelling of the propagation in the new generation fibers [7717-43]

L. Cherbi, U.S.T.H.B Univ. (Algeria); Y. Bouslimani, Univ. of Moncton (Canada)

7717 1A Numerical approximation of scalar diffraction through first order optical systems [7717-45] J. J. Healy, J. T. Sheridan, Univ. College Dublin (Ireland) 
$77171 \mathrm{~B} \quad 5 \mathrm{~Gb} / \mathrm{s}$ optical logic AND operations using by monolithically integrated photodiode and electroabsorption modulator [7717-46]

Y. X. Zhang, L. J. Zhao, B. Niu, J. Q. Pan, W. Wang, Institute of Semiconductors (China)

7717 1C Recording/reproduction simulation of holographic memory using three-dimensional beam propagation method [7717-47]

T. Ohori, S. Yoshida, M. Yamamoto, Tokyo Univ. of Science (Japan)

7717 1D Multiorder varifocal moiré zone plates [7717-48]

Z. Jaroszewicz, Institute of Applied Optics (Poland) and National Institute of

Telecommunications (Poland); A. Kołodziejczyk, Warsaw Univ. of Technology (Poland);

M. S. Millan, L. A. Romero Perez, Univ. Politécnica de Cataluña (Spain); I. Golub, Algonquin College (Canada)

$77171 \mathrm{E}$ A Y-branch light collecting device for natural light guiding system [7717-50]

K.-Y. Chen, Y.-Y. Chen, National Taiwan Univ. of Science and Technology (Taiwan);

J.-C. Chiang, China Univ. of Science and Technology (Taiwan); A. J.-W. Whang, National Taiwan Univ. of Science and Technology (Taiwan)

7717 IF A generalized approach to modeling radiation pattern measurement methods for highpower LEDs [7717-51]

G.-W. Chang, National Taiwan Normal Univ. (Taiwan); C.-C. Liao, National Taiwan Normal Univ. (Taiwan) and National Tsing Hua Univ. (Taiwan); Y.-C. Chen, National Tsing Hua Univ. (Taiwan)

$77171 \mathrm{H} \quad$ An extended Fourier modal method for plane-wave scattering from finite structures [7717-54]

M. Pisarenco, J. Maubach, Eindhoven Univ. of Technology (Netherlands); I. Setija, ASML Netherlands B.V. (Netherlands); R. Mattheij, Eindhoven Univ. of Technology (Netherlands)

$771711 \quad$ Extracting parameters from slanted non-uniform gratings recorded in photopolymer [7717-55]

D. Sabol, M. R. Gleeson, J. T. Sheridan, Univ. College Dublin (Ireland)

$77171 \mathrm{~J}$ Experimental study of primary radical generation in polyvinylalcohol/acrylamide (PVA/AA) based photopolymer material [7717-56]

S. Liu, M. R. Gleeson, J. Guo, J. T. Sheridan, Univ. College Dublin (Ireland)

$77171 \mathrm{~K} \quad$ Zoom systems with tunable-focus lenses [7717-57]

A. Miks, J. Novak, P. Novak, Czech Technical Univ. in Prague (Czech Republic)

$77171 \mathrm{~L}$ Design procedure for planar add-drop multiplexer based on contra-directional coupler and apodized Bragg grating [7717-58]

M. Wielichowski, S. Lis, K. Ptasiński, S. Patela, Wroclaw Univ. of Technology (Poland)

771710 Using short exposures to approximate diffusion rates [7717-61]

C. E. Close, M. R. Gleeson, J. T. Sheridan, Univ. College Dublin (Ireland)

Author Index 
Downloaded From: https://www.spiedigitallibrary.org/conference-proceedings-of-spie on 25 Apr 2023

Terms of Use: https://www.spiedigitallibrary.org/terms-of-use 


\title{
Conference Committee
}

\author{
Symposium Chairs \\ Francis Berghmans, Vrije Universiteit Brussel (Belgium) \\ Ronan Burgess, European Commission (Belgium) \\ Jürgen Popp, Institut für Photonische Technologien e.V. (Germany) \\ Peter Hartmann, SCHOTT AG (Germany) \\ Hugo Thienpont, Vrije Universiteit Brussel (Belgium)
}

\section{Conference Chairs}

Frank Wyrowski, Friedrich-Schiller-Universität Jena (Germany)

John T. Sheridan, University College Dublin (Ireland)

Jani Tervo, University of JoensuU (Finland)

Youri Meuret, Vrije Universiteit Brussel (Belgium)

Program Committee

Pierre Ambs, Université de Haute Alsace (France)

Pierre H. Chavel, Laboratoire Charles Fabry (France)

Zbigniew Jaroszewicz, Instytut Optyki Stosowanej (Poland)

Bahram Javidi, University of Connecticut (United States)

Norbert Lindlein, Friedrich-Alexander-Universität Erlangen-Nürnberg (Germany)

M. G. Moharam, CREOL, The College of Optics and Photonics, University of Central Florida (United States)

Cristian Neipp López, Universidad de Alicante (Spain)

Vladimir S. Pavelyev, Image Processing Systems Institute (Russian Federation)

Hagen Schimmel, LightTrans GmbH (Germany)

Colin J. R. Sheppard, National University of Singapore (Singapore)

Boris Spektor, Technion-Israel Institute of Technology (Israel)

Jari P. Turunen, University of Joensuu (Finland)

\section{Session Chairs}

1 Subwavelength Structures

Jani Tervo, University of Joensuu (Finland)

2 Wave Optics I

Jani Tervo, University of Joensuu (Finland) 
3 New Strategies in Optical Design

Youri Meuret, Vrije Universiteit Brussel (Belgium)

$4 \quad$ Illumination Systems

Youri Meuret, Vrije Universiteit Brussel (Belgium)

$5 \quad$ Holographic Modelling

John T. Sheridan, University College Dublin (Ireland)

6 Wave Optics II

Uwe D. Zeitner, Fraunhofer-Institut für Angewandte Optik und Feinmechanik (Germany) 